\title{
Preservation of Bancakan Tradition in Strengthening Indonesia's National Identity
}

\author{
Ridwan Hasyim and Rahmat Rahmat \\ Civics Department, School of Postgraduate \\ Universitas Pendidikan Indonesia \\ Bandung, Indonesia \\ ridwanhasyim125@gmail.com
}

\begin{abstract}
The socio-cultural wealth of Indonesian plural and compound societies provides a different culture in each region. This article discusses the preservation of Bancakan tradition that is held by the villagers of Gegesik Lor as one of the factors that strengthen national identity. This research was conducted to find out the preservation of Bancakan tradition, it is done by Gegesik Lor village community so it can strengthen national identity. The approach used is qualitative approach with case study method. Preservation of Bancakan tradition is done by optimizing the role of education in family and community. The research found that the preservation of Bancakan traditions can strengthen the national identity of Indonesia because the national identity of the Indonesian nation is unearthed from the richness of local culture.
\end{abstract}

Keywords-preservation of culture; Indonesia; national identity

\section{INTRODUCTION}

Preservation of traditions and other cultural elements in Indonesia has been urgent to do. Based on the Law of the Republic of Indonesia Number 5 Year 2017 on the Promotion of Culture stated that the regional culture is the wealth and identity of the nation that is needed to advance the national culture of Indonesia amid the dynamics of world development. Indonesia as a plural and compound country provides opportunities for the preservation of local culture that can strengthen national identity. The peaks of regional culture and the result of cross-cultural region are the national culture that can strengthen the national identity [1]. In other words, ethnic identity can contribute to national identity [2], ethnic identity refers to exclusive attributes such as ancestors and indigenous cultures [3].

Preservation of Bancakan tradition as local wisdom of Gegesik Lor village community is a strategic step in strengthening national identity of Indonesian. As a compound and plural country, Indonesia has a consequence of accepting every regional culture as the national identity of Indonesia. Moreover, in the tradition of bancakan there are important values that affect for better social life. All elements and values included in the culture determine national identity because national culture form a national identity [4].

\section{THEORETICAL}

\section{A. The Preservation of tradition}

The preservation of tradition is the effort of protection, development and utilization of a habit from a group of the cultural proponent community who's their distribution and inheriting takes place as hereditary [5]. Tradition as contained in its regulation is a custom developed in the life of society.

Preservation of tradition does not mean the effort to preserve habit in general, but in this context is an intangible cultural form. Preservation of cultural heritage not only deals with physical objects such as buildings and surroundings, but also intangible objects such as art, and customs or habits [6].

\section{B. National Identity}

For the state of Indonesia, the national identity starts from the nationality identity and then raises the national identity of the nation-state of Indonesia. The unity of the Indonesian nation through various phrases it refers to a kinship system, it is reflected in the use of the word "motherland" (referring to "homeland" indirectly describing the natural unity). In that bond people feel the beauty of the community (gemeinschaft) [7].

The national identity of the Indonesian consists of the national language or the unity it is the Indonesian language, the national philosophy of Pancasila, the national anthem of Indonesia Raya, the symbol of the state is Garuda Pancasila, the motto of the state is Bhinneka Tunggal Ika, the state flag of Sang Saka Merah Putih, constitution of State is The Constitution of the Republic of Indonesia Year 1945, the form of united states is the Republic of Indonesia, the concept of insight of the archipelago, as well as local culture accepted as a national culture [8].

The Plurality exist in Indonesia has influenced many factors of national identity. National identity for nation-states such as Indonesia involved the consensus of the past that is preserved until now, as well as local wisdom that lives and thrives in local communities. Therefore, national identity is multidimensional [9], all indications of social habits, lifestyles and public confidence are included in national identity [10]. 


\section{Preservation of Traditions in Strengthening Indonesia's National Identity}

Traditional preservation can strengthen Indonesia's national identity because tradition is part of culture. While the culture in Indonesia has been recognized as part of national identity. Indonesian society is multi-ethnic, multi-religious and multiideological with various elements in the community life areas are the seeds that can enrich the cultural heritage to build a strong nation [11].

Indonesia's various formed of around 726 tribes, each of them has its own values and powers that can be donated to the formation of national culture and can form a national identity [12]. Because of national culture establishes a national identity, all elements and values that include in the culture determine national identity [4]. Indonesia has strong principles and visions of nationalism by allowing for the diversity of communities they are not uprooted from each traditional roots and histories so they show the richness of cultural region or local cultures, it is an important element in strengthening national identity [1].

\section{METHOD}

This research was conducted to find out the form of preservation of Bancakan tradition it is done by Gegesik Lor village community so it can strengthen national identity. The approach used is qualitative approach with case study method. Case study is an in-depth exploration of bounded systems (e.g., activities, events, processes, or individuals) based on extensive data collection (Creswell, 2015). This research uses data collection techniques such as interviews, observations and literature studies.

\section{RESULT AND DISCUSSION}

From the deepen interviews that to be done with full responsibility in Gegesik Lor village, we found that the process of preserving the Bancakan tradition is done by citizens, it emphasizes to the important role of the family as the first educational institution and society as a place of inherited tradition from generation hereditary. When parents giving advice actually they do not declare directly to hold the tradition bancakan but the children have known a form of manifestation as a gratitude in the community, it through the tradition of bancakan because it has been happened hereditary in the community environment.

The preservation of tradition requires the active role of the community as native speakers of that tradition. Without the community's active role in its inheriting, the tradition will not survive for long time despite being regulated in the Constitution. The continuity of a tradition lies in the hands of a society it is supported by the Government as a policy maker. Tradition can live because of society, can die because of society. The government only "fences". Because the society is an object so it will be back to the community, in addition to the government make the rule of law and the signs.

Society still holds the tradition because of needed. Mainly the various sense, there are mutual cooperation, sharing the feeling, dividing of prosperity, expression of gratitude for health and physical given so they do the gratitude action in form of bancakan. The people are enthusiastic because they are happy with the bancakan tradition. Bancakan tradition is still held in Gegesik Lor village community because there is a society needed, if they do not do this tradition they will feel discomfort. There is a sense of reciprocal relationship among the societies, there is mutual relations between citizens. There are clear social ties among the people (Respondent Joko, 2018).

The people of Gegesik Lor village are committed to preserving the bancakan tradition in order to be inherited to the next generation hereditary. The children have known the tradition because of their curiosity and deliberately implanted by their parents. There is the role of parents and community in introducing the tradition. The people of Gegesik Lor village know the tradition not only told by the parents but also, they are involved (learning by doing). The people tell the noble value of the bancakan tradition and it is will continue to their future grandchildren. The people have attached with this tradition. It has become a local wisdom because every get happiness or safety they will be bancakan (Respondent Supandi, 2018).

All citizens are interviewed believed that the bancakan tradition was a manifestation of gratitude to Allah (Lord of Hosts) done by eating together in a large tray. People who always do bancakan believed their life will be harmonious (harmonious), they eat in a tray of four or five to be harmonious (Respondent Dakami, 2018, Respondent Sukasa, 2018). The form of this tradition is the local wisdom of the Javanese society with the characteristic of combining togetherness and respect in human being, human with nature, human with God [14].

Bancakan tradition is still developing until now in Gegesik Lor village communities, it still survives in the middle of foreign cultural strikes that enter through globalization. Bancakan tradition is not only symbolizes the power of the value system so it can survive until today. The bancakan tradition also represents a common life. Eating together on a tray is nothing else because of the being together value, there is not discriminating with race, tribe, status, environment. The tray symbolizes the state, the earth, the unity of society, they do not vie of the difference (Respondent Kusdono, 2018).

Bancakan tradition can strengthen national identity if promoted and encouraged by the central government to each region. Because of the positive values contained in it, its accordance with the nation identity. The Cultures that have noble values of the nation can be categorized as national identity. The existence of tradition and culture requires the rule of law as a form of protection to keep from being destroyed by entering foreign culture. Regional culture is needed to strengthen national culture, because national culture without regional culture is not available because the origin of national culture come from the region. The nation of Indonesia requires the actualization of regional culture because culture reflects the national identity, Indonesia is known for Yogyakarta, Bali, Cirebon, because there is special thing of these areas (Respondent Joko, 2018). The national culture takes on local culture, which has its own distinctive features. Especially if it 
has positive values. The government must support and uphold local culture so that local culture will be famous and worldwide (Respondent Kusdono, 2018).

\section{CONCLUSION}

Preservation of bancakan tradition has succeeded to be inherited from one generation to the next generation because it optimizes the role of education in family and society. In the family environment, parents provide trust to the children so that when they get happiness they have to express the gratitude which is formed by bancakan tradition. In addition, the community plays a role in persuading all layers of community including children are invited to actively engage in bancakan traditions resulting in the process of "learning by doing." Preservation of bancakan traditions can strengthen the national identity of Indonesia because the national identity of the nation of Indonesia is excavated from the richness of local culture.

\section{ACKNOWLEDGMENT}

We would like to thank for our beloved parents and beloved families who have given us the opportunity to become knowledgeable people, as well as thanks to the Indonesia University of Education which has become a place for us to get useful science and knowledge.

\section{REFERENCES}

[1] Latif. Y, Negara Paripurna: Historisitas, Rasionalitas dan Aktualitas Pancasila. Jakarta: Gramedia Pustaka Utama, 2015.
[2] Gong. L, "Ethnic Identity and Identification with The Majority Group: Relations with National Identity and Self-Esteem," International Journal of Intercultural Relations, vol. 31, pp. 503-523, 2007.

[3] Ha. S. and Jang. S, "National Identity in a Divided Nation: South Koreans' Attitudes Toward North Korean Defectors and The Reunification of Two Koreas," International Journal of Intercultural Relations, vol. 55, pp. 109-119, 2016.

[4] Gelisli. Y. and Beisenbayeva. L, "Opinions of The University Students Studying in Kazakhstan About National Identity. Procedia," Social and Behavioral Sciences, vol. 197, pp. 486-493, 2015.

[5] Peraturan Menteri Pendidikan dan Kebudayan Republik Indonesia Nomor 10 Tahun 2014.

[6] Prompayuka. S. and Chairattananon. P, "Preservation of Cultural Heritage Community: Cases of Thailand and Developed Countries," Procedia - Social and Behavioral Sciences, vol. 234, pp. 239-243, 2016.

[7] Anderson. B, Imagined Communities (Komunitas-Komunitas Terbayang). Alih bahasa oleh Daniel Dhakidae. Yogyakarta: Pustaka Pelajar \& Insist Press, 2018.

[8] Winarno. D, Paradigma Baru Pendidikan Kewarganegaraan: Panduan Kuliah di Perguruan Tinggi. Jakarta: PT Bumi Aksara, 2006.

[9] Tranter. B. and Donoghue. J, "National Identity and Important Australians," Journal of Sociology 2015, vol. 51(2), pp. 236-251, 2015.

[10] Gelisli. Y, "Values of National Identity in Child Magazines," Procedia Social and Behavioral Sciences, vol. 116, pp. 3308 - 3312, 2014

[11] Poespowardojo, Pancasila sebagai Ideologi: Dalam Berbagai Bidang Kehidupan Bermasyarakat, Berbangsa dan Bernegara. Jakarta: BP-7 Pusat, 1992.

[12] Tilaar. H, Mengindonesia: Etnisitas dan Identitas Bangsa Indonesia. Jakarta: Rineka Cipta, 2007.

[13] Creswell. J, Riset Pendidikan: Perencanaan, Pelaksanaan dan Evaluasi Riset Kualitatif dan Kuantitatif. Yogyakarta: Pustaka Pelajar, 2015.

[14] Supriyadi, "In Search of the Power of Javanese Culture against the Cultural Urbanization in Kotagede, Yogyakarta-Indonesia," Procedia Social and Behavioral Sciences, vol. 68, pp. 676-686, 2012. 